\title{
Right Atrial Lipoma
}

\author{
Paulo M. Pêgo-Fernandes, Pedro Luiz Guimarães Costa, Fábio Fernandes, \\ Luiz Alberto Benvenuti, Sérgio Almeida Oliveira \\ São Paulo, SP - Brazil
}

\begin{abstract}
Benign cardiac tumors are rare, and lipomas are among those less frequently found. We report the case of a 48-year-old male complaining of high blood pressure and epistaxis in the last 2 months, with a diagnosis of right atrial lipoma established on echocardiography, magnetic resonance imaging, and anatomicopathological examination. The tumor was successfully removed, and up to 42 months after surgical excision, no evidence of tumor relapse was observed.
\end{abstract}

Primary cardiac tumors are rare, not easily clinically diagnosed, and differ in regard to clinical manifestations, location, morphology, size, and radiological findings ${ }^{1}$.

The incidence of primary tumors of the heart and pericardium ranges from $0.02 \%$ to $0.28 \%$, according to a series of autopsies reported by McAllister $\mathrm{HA} \mathrm{Jr}^{2}$. On the other hand, neoplasias, mainly mammary and pulmonary neoplasias (that send more metastases to the heart), followed by leukemias and lymphomas are 10 to 40 times more frequent than primary cardiac tumors. Cardiac metastases are found in the autopsies of $10 \%$ of the patients who die from pulmonary cancer and of $25 \%$ of those with tumors in other organs. In children, cardiac tumors are rare, not exceeding $10 \%$ of all neoplasias in this age bracket ${ }^{3}$.

Approximately $75 \%$ of the primary cardiac tumors are benign ${ }^{4}$, myxomas being the most common, followed by rhabdomyomas, lipomas, fibromas, and teratomas ${ }^{3}$. Cardiac lipomas, initially reported by Orth in $1886^{5}$, account for $8.4 \%$ of the primary tumors of the heart and pericardium. Until 1990, 63 had been reported ${ }^{6}$. According to the available literature, $25 \%$ of cardiac lipomas are intramyocardial, $25 \%$ are extracavitary of epicardial origin, and $50 \%$ are intracavitary of subendocardial origin - those of the right atrium are extremely rare ${ }^{7}$.

Instituto do Coração do Hospital das Clínicas - FMUSP

Mailing address: Paulo Manuel Pêgo-Fernandes - InCor - Divisão Cirúrgica - Av. Dr. Enéas C. Aguiar, 44 - $2^{\circ}$ andar - 05403-000 - São Paulo, SP, Brazil - E-mail: paulopego@incor.usp.br

English version by Stela Maris C. e Gandour
In the recent literature, a case of intrapericardial lipoma in a 27 -year-old female ${ }^{8}$ and a case of right atrial lipoma in a 54-year-old male have been reported ${ }^{9}$. In 1994, Diamante et al ${ }^{10}$ reported a peculiar case of epicardial lipoma that caused inversion of the left atrial auricle and partial obstruction of the drainage of the left pulmonary veins, leading to pulmonary and systemic arterial hypertension, cardiomegaly, and electrocardiographic changes. In a study of 50 cases of primary cardiac neoplasias by Fernandes et al ${ }^{11}$, only 1 lipoma was reported.

\section{Case Report}

The patient was a 48-year-old male who complained of high blood pressure and epistaxis for 2 months. He denied similar previous episodes. He also reported being an exsmoker (2 packs per day) for 20 years and denied alcoholism. His personal and familial antecedents were not relevant.

At the time of the symptoms, the patient visited a cardiologist. Due to the nonspecificity of the symptoms, an echocardiography (7/2/98) was performed and revealed a right atrial tumor of $4.6 \times 3.5 \mathrm{~cm}$ with characteristics of adipose tissue.

The patient was referred to our service. On physical examination, he was in good general condition, eupneic, acyanotic, and had no fever. His blood pressure was 130/ $80 \mathrm{mmHg}$, his heart rate was $60 \mathrm{bpm}$, and the rest of his physical examination was within the normal range.

The laboratory tests showed a mild leukocytosis $\left(13,900\right.$ cells $\left./ \mathrm{mm}^{3}\right)$ with no deviation to the left. The remaining tests were within the normal range.

The chest X-ray showed normal pulmonary transparency, normal hila, free diaphragmatic sinuses and cupula, and a normal cardiac image.

The electrocardiography detected sinus rhythm of 72 bpm with deviation of the cardiac axis to the left.

The nuclear magnetic resonance imaging (8/17/98) confirmed the echocardiographic findings in another institution: tumor of $4.6 \times 3.5 \mathrm{~cm}$ in the coronal direction, with characteristics of adipose tissue, located in the right atrial ceiling, suggestive of lipoma (fig. 1). 


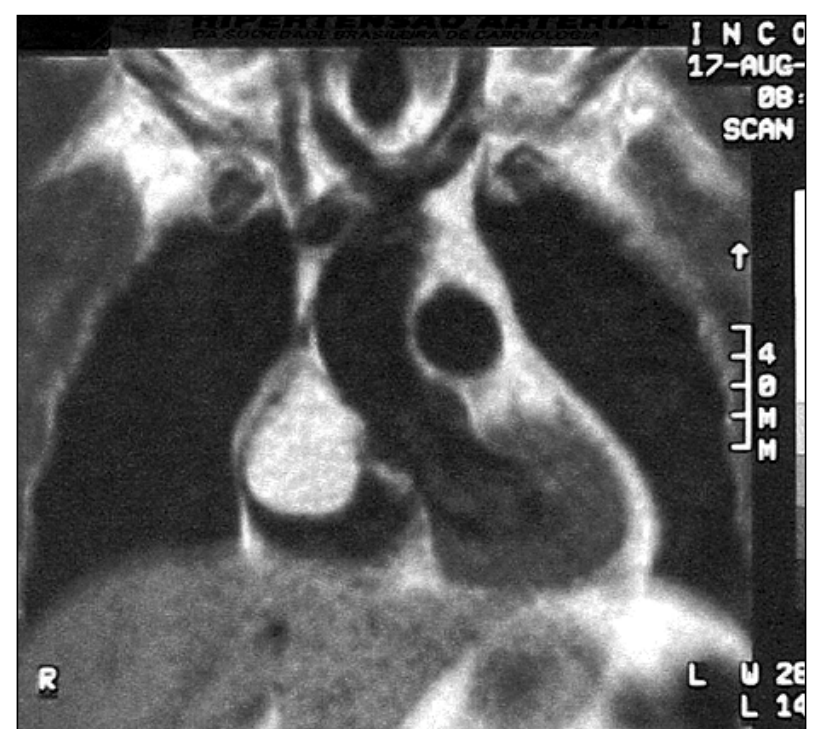

Fig. 1- Nuclear magnetic resonance imaging showing the right atrial tumor.

Considering the diagnosis and the good conditions of the patient, we chose to excise the tumor mass. The patient underwent extracorporeal circulation with cannulation of the aorta and venae cava. Once the right atrium was opened, the implantation of the tumor could be seen close to the tricuspid ring. Blunt dissection and cauterization of the implantation site were performed. The therapeutical process was successful and uneventful (figs. 2 and 3).

The anatomicopathological examination of the tumoral mass revealed a round formation of $5.0 \times 4.5 \times 4.0 \mathrm{~cm}$, weighting $35 \mathrm{~g}$, constituted of macroscopically uniform yellow tissue with peripheral focal areas of brownish tissue. On frozen examination, lipoma was diagnosed, and this was the definite histological diagnosis (fig. 4).

Echocardiographies were performed 8 days and 7 months after the removal of the lipoma, and a normal right atrium was observed. No relapse was reported up to 42 months after the removal of the tumor.

\section{Discussion}

In the literature, lipomas are reported as infrequent

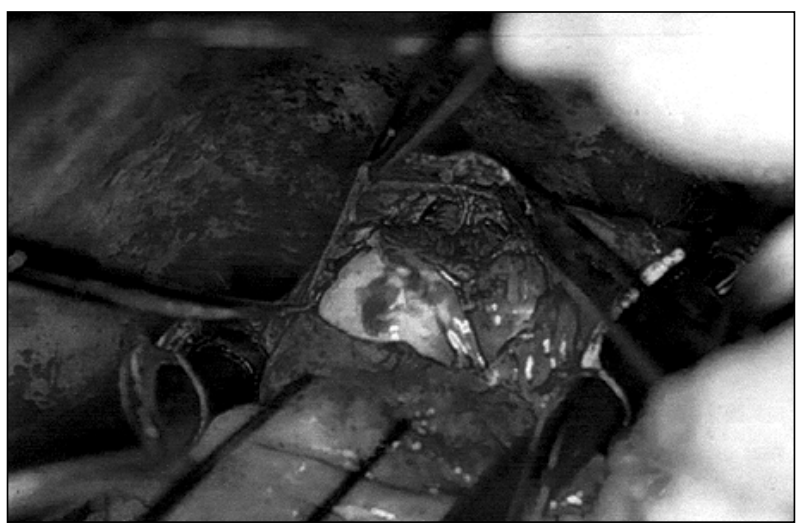

Fig. 2 - Phase of tumor resection.

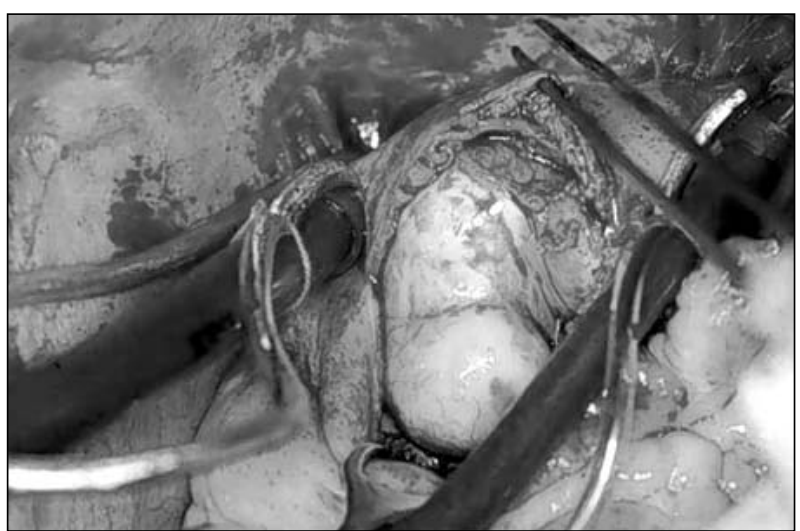

Fig. 3 - Appearance of the tumor after its resection.

neoplasias, accounting for $8.4 \%$ of the primary cardiac tumors, those in the right atrium being extremely rare $^{6}$.

According to their composition and location, lipomas are subdivided into 2 groups: lipomatous hypertrophy and true lipoma. The latter is less frequent and present as an encapsulated mass of adipose tissue.

When infiltrated in the myocardium, the tumor is called myolipoma; if fibroblasts are present, the tumor is called fibrolipoma; and when it has thymic cells, the tumor is called thymolipoma or lipothymoma. If the tumor consists only of lipocytes, it is a lipoma ${ }^{12}$. This tumor has a congenital origin, belonging to the group of the homeoplastic dysembryomas, and is described as an encapsulated collection of benign adipose cells, frequently containing muscle fibers ${ }^{13,14}$. The hypothesis of acquired disease is not accepted, because the individuals with intrathoracic lipomas do not have other related diseases ${ }^{12}$.

The diagnosis of this tumoral entity is difficult, because most patients are asymptomatic or have variable symptomatology, depending on the size and intracavitary location of the tumor. Therefore, as with other primitive cardiac tumors, its diagnosis is often accidental and almost exclusively an autopsy finding ${ }^{15}$. Lipomas may be detected on radiographic examinations and diagnosed on echocardiography, computerized tomography, and nuclear magne-

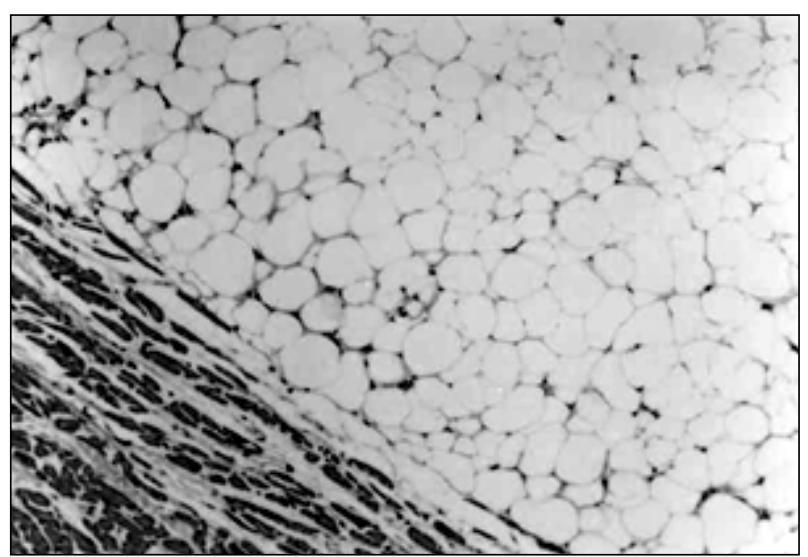

Fig. 4 - Anatomicopathological examination - tumor consisting of mature adipose cells with cardiac tissue at the margin-lipoma. HE, x 160. 
tic resonance imaging, which provide more information regarding their nature, size, location, and pattern ${ }^{16,17}$.

Because they are frequently asymptomatic, the patients with lipomas usually do not require any treatment or surgical intervention, depending on the location and size of the tumor. However, large subpericardial lipomas, exerting pressure on the cardiac structures, may determine angina or interfere with the cardiac function, while intramyocardial lipomas may cause changes in electrical conduction and arrhythmias ${ }^{6}$ and may result in sudden death.

Although most cases of sudden death are due to atherosclerotic disease, approximately $0.0025 \%$ result from primary cardiac tumors. Until 1996, 120 cases of sudden death attributed to these tumors had been reported, $86 \%$ of them being histologically benign. However, the intracardiac location caused hemodynamic and conduction changes, resulting in sudden death ${ }^{18}$.
Therefore, whenever the tumor has an intracavitary location, it should be resected ${ }^{6}$, because early surgical excision may allow complete cure, prevent sudden death and irreversible heart failure ${ }^{19}$. However, the choice of a surgical therapy for asymptomatic patients with a cardiac tumor is critical, because the lesion is not always related to alterations in function, the patients are usually asymptomatic, and the tumors are occasional autopsy or examination findings. However, these tumors may be related to valvar dysfunction, thoracic pain, congestive heart failure, neurological symptoms, and sudden death ${ }^{20}$.

Our patient, who had a cardiac tumor mass characterized as right atrial lipoma, underwent tumor resection, justified by the risk of late complications in cardiac function or even sudden death. The surgery was successful, and the patient is in excellent clinical condition 3 and a half years after the procedure.

\section{References}

1. AraozPA, Eklund HE, Welch TJ, Breen JF.CT and MR imaging of primary cardiac malignancies. Radiographics 1999; 19: 1421-34.

2. McAllister, HA Jr. Tumors of the heart and pericardium. In: Silver, MD, ed. Cardiovascular Pathology. $2^{\text {nd }}$ ed. New York: Churchill Livinstone Inc. 1991; 2: 1297-333.

3. Iglézias JCR, Velloso LGC, Dallan LA, Benvenuti LA, Verginelli G, StolfNAG. Angiossarcoma de átrio direito. Rev Bras Cir Cardiovasc 2000; 15: 186-91.

4. Heath D. Pathology of cardiac tumors. Am J Cardiol 1968;21:315-27.

5. Orth JJ.Lehrbuch der Speciellen Pathologischen Anatomie. Berlin: Hirschwals, 1987: 201.

6. Vanderheyden M, De Sutter J, Wellens F, Andries E. Left atrial lipoma: case report and review of the literature. Acta Cardiol 1998; I: 31-2.

7. Grande AM, Minzioni G, Pederzolli C, et al. Cardiac lipomas. J Cardiovasc Surg 1998; 39: 813-15.

8. Albanesi Filho FM, Castier MB, Sá VF, Oliveira FEF, Jazbik W, Gomes Filho JBM. Lipoma intrapericárdico. Arq Bras Cardiol 1991; 56: 309-312.

9. Silveira WL, Nery MW, Soares ECG, et al. Lipoma de átrio direito. Arq Bras Cardiol 2001; 77: 361-4.

10. Diamante L, Lion MF, Moreira AELC, et al. Inversão de aurícula esquerda por lipoma epicárdico: comportamento atípico de um tumor levando a obstrução de veias pulmonares. Arq Bras Cardiol 1994; 62: 207-10.

11. Fernandes F, Soufen HN, Ianni BM, Arteaga E, Ramires JAF, Mady C. Primary neo- plasms of the heart: clinical and histological presentation of 50 cases. Arq Bras Cardiol 2001; 76: 235-7.

12. Medeiros Sob JH, Kambara AM. Tumor radiotransparente epipericárdico e epimiocárdico: lipoma ou timolipoma. Revista da Imagem 1986; 8:27-34.

13. Colucci MS, Braunwald E. Primary tumors of the heart. In: Braunwald E, ed. Heart Disease: A Textbook of Cardiovascular Medicine. $4^{\text {th }}$ ed. Philadelphia: WB Saunders Co. 1992: 1451.

14. McNamara RF, Taylor AE, Panner BJ. Superior vena caval obstruction by lipomatous hypertrophy of the right atrium. Clin Cardiol 1987; 10: 609-10.

15. Calamida R, Dessalvi F, Pistis L, Catani G. Morte improvvisa da amartoma lipomatoso del cuore. G Ital Cardiol 1996; 26: 1421-4.

16. Tuna IC, Julsrud PR, Click RL, et al. Tissue characterization of an unusual right atrial mass by resonance imaging. Mayo Clin Proc 1991; 66: 498-501.

17. Mullen JC, Schipper SA. Sett SS, Trusler GA. Right atrial lipoma. Am Heart J 1982; 104: 276-88.

18. Cina SJ, Smialek JE, Burke AP, Virmani R, Hutchins GM. Primary cardiac tumors causing sudden death: a review of the literature. Am J Forensic Med Pathol 1996; 17: 271-81

19. Mendes RGG, Evora PRB, Pansani JA, Moraes MMFS, Mendes JA, Ribeiro PJF. Leiomiossarcoma atrial esquerdo. Arq Bras Cardiol 1994; 63: 497-500.

20. Benvenuti LA, Mansur AJ, Lopes DO, Assis RVC. Primary lipomatous tumors of the cardiac valves. South Med J 1996; 89: 1018-20. Anatomie. Berlin, Hirschwals. 1987, 201 